\title{
THE FIRST RECORD OF THE COSMOPOLITAN SLUG DEROCERAS LAEVE (O. F. MÜLLER, 1774) (GASTROPODA: PULMONATA: AGRIOLIMACIDAE) IN BHUTAN
}

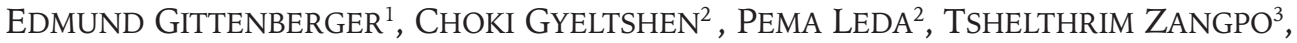 \\ RIEKS DEKKER VAN KLINKEN ${ }^{3,4 *}$
}

\begin{abstract}
${ }^{1}$ Naturalis Biodiversity Center, Pesthuislaan 7, 2333 Leiden, The Netherlands
(e-mail: edi.gittenberger@naturalis.nl)

${ }^{2}$ National Biodiversity Centre, Serbithang, Thimphu, Bhutan

(e-mail: chokig@gmail.com; pemled12@gmail.com)

${ }^{3}$ National Plant Protection Centre, Semtokha, Thimphu, Bhutan (e-mail: tzangpo@moaf.gov.bt)

${ }^{4}$ CSIRO, 41 Boggo Rd, Dutton Park, 4001 Brisbane, Australia (e-mail: rieks.vanklinken@csiro.au)

*corresponding author
\end{abstract}

\begin{abstract}
The cosmopolitan slug Deroceras laeve (O. F. Müller) is reported from Bhutan for the first time, with the identity at one site confirmed through dissection. Here it was a minor pest of cabbage on a single farm at 2,780 $\mathrm{m}$ a.s.l. in north-western Bhutan. Two further, anatomically unconfirmed, records suggest that it is widespread in Bhutan. This, together with evidence that it is already widely distributed in nearby countries, suggests that it might have been in Bhutan for some time. Surveys are required to confirm its distribution and pest status in Bhutan, but current indications are that it is a very localised and occasional pest that can be readily managed through manual removal.
\end{abstract}

KEY WORDS: terrestrial slug, introduced, synanthropic, plant pest, Himalaya, cabbage, Brassica

\section{INTRODUCTION}

Bhutan is a small mountainous Himalayan country. The agricultural sector is small but important, with $56.2 \%$ of people employed in farming (RNR 2015). A major plant protection research and development programme was conducted in Bhutan from 1985 to 2000 (DOE DOE 2009), and this included the production of a checklist of insects and mites (BIGGER et al. 1988). Molluscs were not referred to in the checklist, are not represented in the National Plant Protection Centre Collection, and to our knowledge were not recorded in reports and extension material subsequently produced during that programme. Slugs were found damaging cabbages (Fig. 1) during a farm visit in 2016. Samples were sent to the first author for identification within the scope of a more general inventory of the molluscan

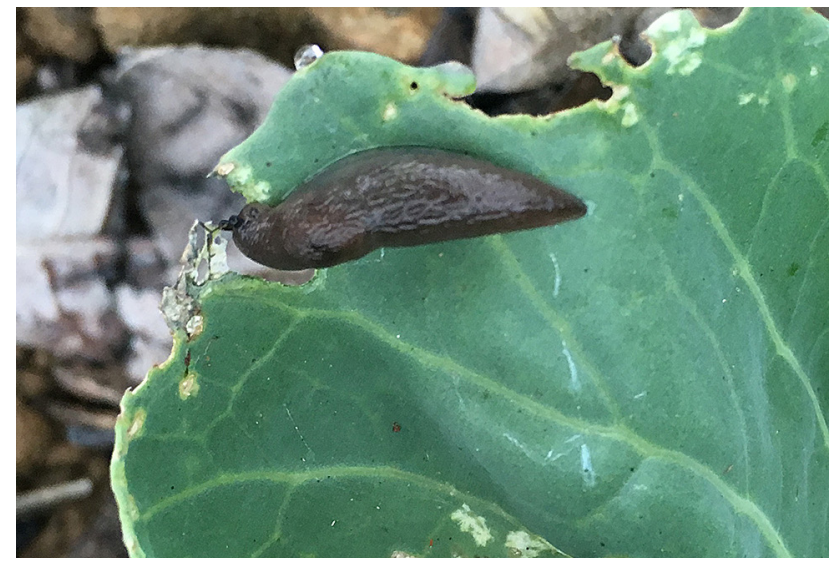

Fig. 1. Deroceras laeve damaging cabbage near Gasa (Photo: RIEKS VAN KLINKEN) 
fauna of Bhutan. Upon dissection the slugs could be identified as Deroceras laeve (O. F. Müller, 1774), a pest species with a nearly worldwide distribution

\section{MATERIAL AND METHODS}

A sample of four slugs was collected on 18 October 2016 by RIEKS VAN KLINKEN at a small (approximately $1 \mathrm{ha})$ farm $\left(27^{\circ} 54^{\prime} 22.3^{\prime \prime} \mathrm{N}, 89^{\circ} 43^{\prime} 59.9^{\prime \prime} \mathrm{E}\right.$; altitude $2,780 \mathrm{~m}$ a.s.l.) which is located within a few hundred metres of Gasa township, the small capital of Gasa District (also known as Gasa Dzongkhag). The rain-fed farm (Fig. 2) is located on a small plateau and was growing diverse summer crops including garlic, radish, cabbages and chilli. Weather is cool temperate, with most rain falling in the summer months. Average monthly temperatures range from $3{ }^{\circ} \mathrm{C}$ to $17^{\circ} \mathrm{C}$. Soils were heavy, and beds were built up to maximise drainage and minimise waterlogging.

Because the genus Deroceras Rafinesque, 1820 is very speciose, and external characters are not diagnostic, dissection is necessary for a reliable identification. Three specimens (preserved in ethanol 70\%, body lengths 17,16 and $13 \mathrm{~mm}$ ) were dissected. The anterior parts of the genital tract, in particular the size and shape of the penis, were studied. Using the largest slug, a transparent genital slide was made by transferring the organs stepwise from ethanol $70 \%$

\section{RESULTS}

The preserved slugs (Fig. 3) are slender with a blunt dorsal keel near the end of the tail; the mantle measures a little less than half the total body size. The dorsal part of the slug is rather dark, brownish grey, with fine irregular spots. Towards the sides the animals become gradually much lighter in colour. that is generally considered either Palaearctic or Holarctic in origin (see Discussion). Here we present data on this record.

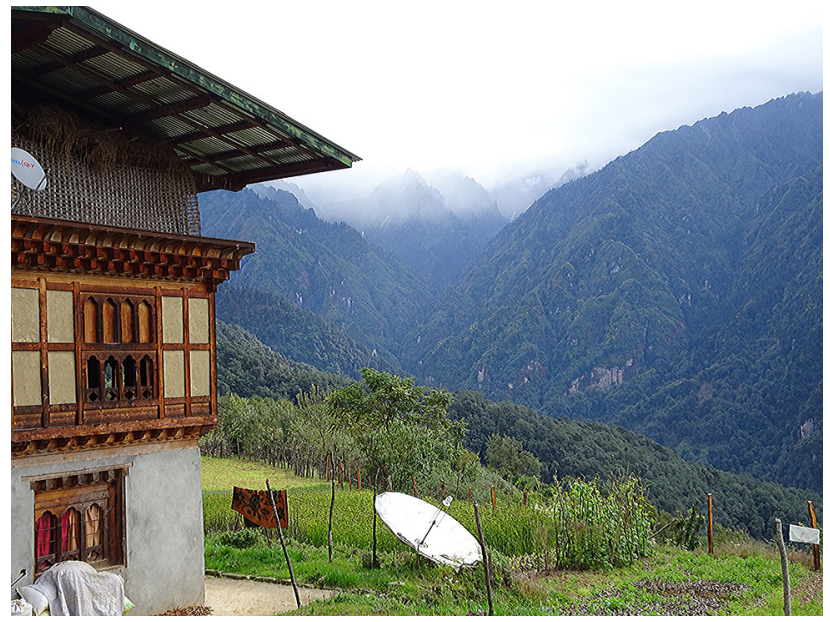

Fig. 2. The farm near Gasa (Photo: RIEKS VAN KLINKEN)

with cochineal dye added, to ethanol $100 \%$, then to Euparal essence/ethanol, then Euparal essence, and finally to Euparal for fixation. The smallest slug in the sample, $12 \mathrm{~mm}$ long in $70 \%$ ethanol, was not dissected.
The three dissected slugs were all sexually mature. Two of these were euphallic, i.e. provided with a fully developed male part of the genital tract, whereas the smallest one was aphallic, i.e. with only a rudimentary penis. The penis of the euphallic slugs, illustrated in situ (Fig. 4) and prepared (Figs 5, 6), is a slender, twisted tube without any appendices.

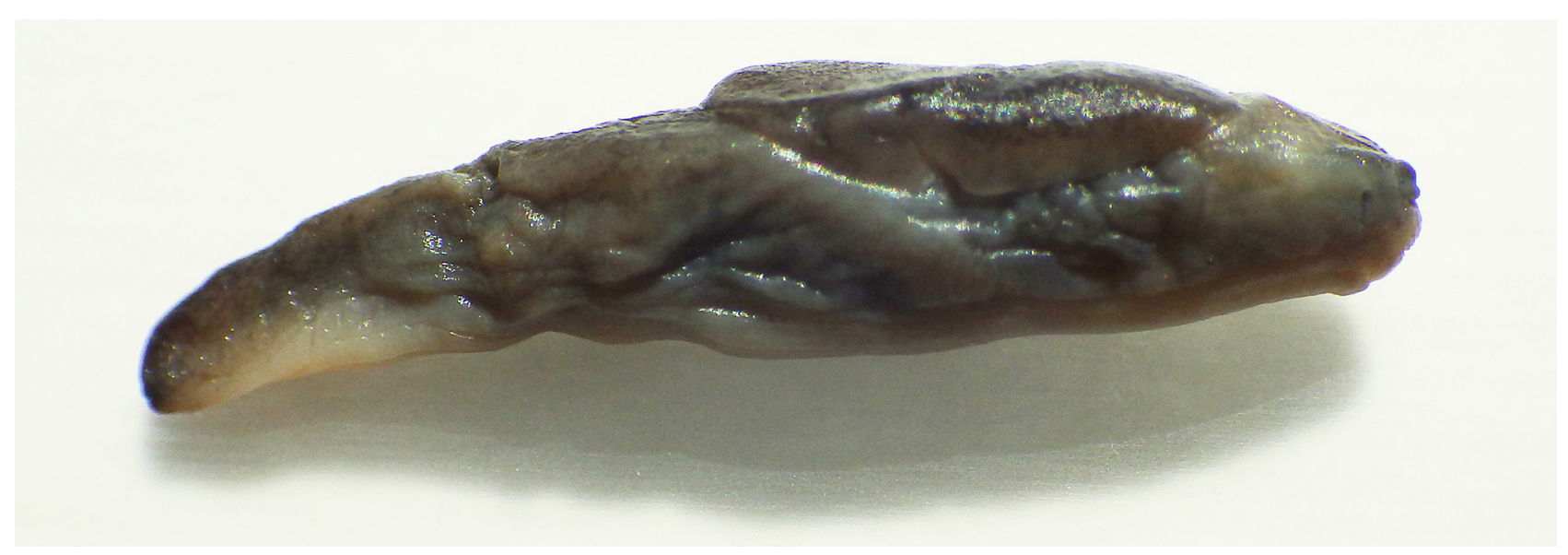

Fig. 3. Deroceras laeve preserved in $70 \%$ ethanol. Near Gasa as in Figs 1 and 2. Length $17 \mathrm{~mm}$ 


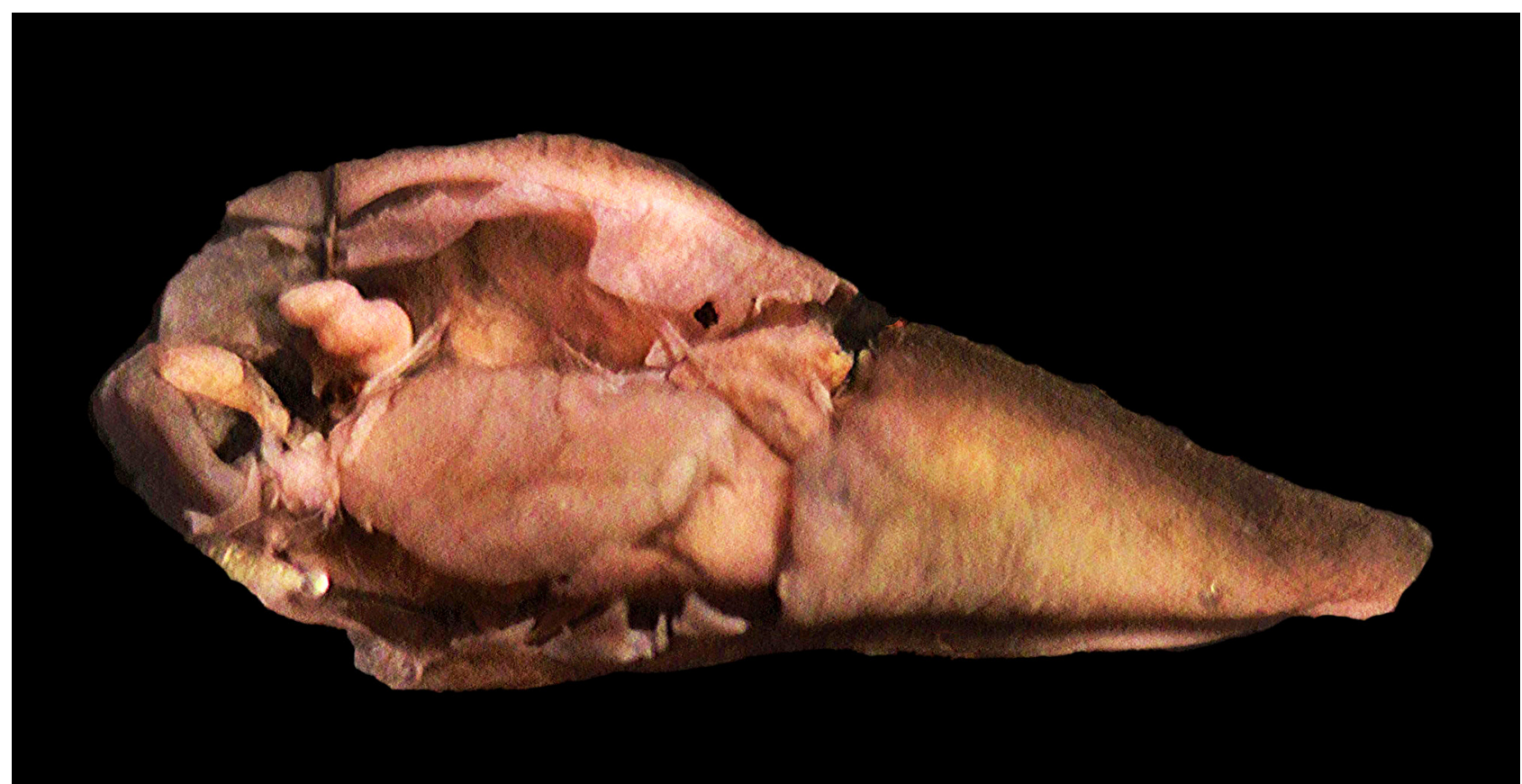

Fig. 4. Deroceras laeve, situs viscerum showing the proximal parts of the genital tract in situ. The pin is used to lift the diagnostic twisted penis

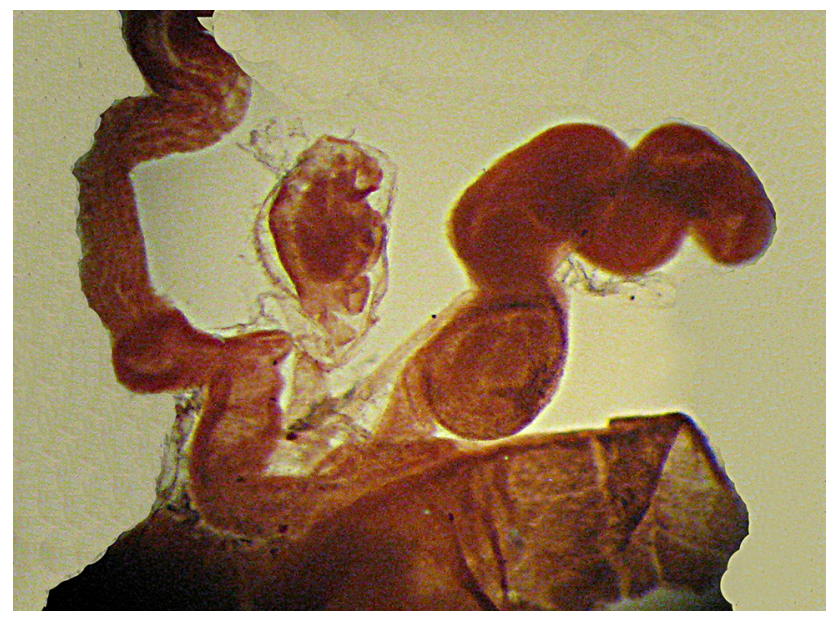

Fig. 5. Deroceras laeve, anterior parts of genital tract, photographed. From left to right: oviductus, spermatheca and penis (see Fig. 6)

\section{DISCUSSION}

This is the first confirmed record of $D$. laeve in Bhutan. At this site in Gasa an average of approximately one slug per pre-heading cabbage plant was causing significant crop damage across a small field. Systematic census has not been conducted, and the National Plant Protection Centre (NPPC), responsible for plant protection research and development in Bhutan, has not received reports of widespread problems caused by slugs. However, the first author identified two additional photographic records as potentially $D$. laeve (Fig. 7). One was report-

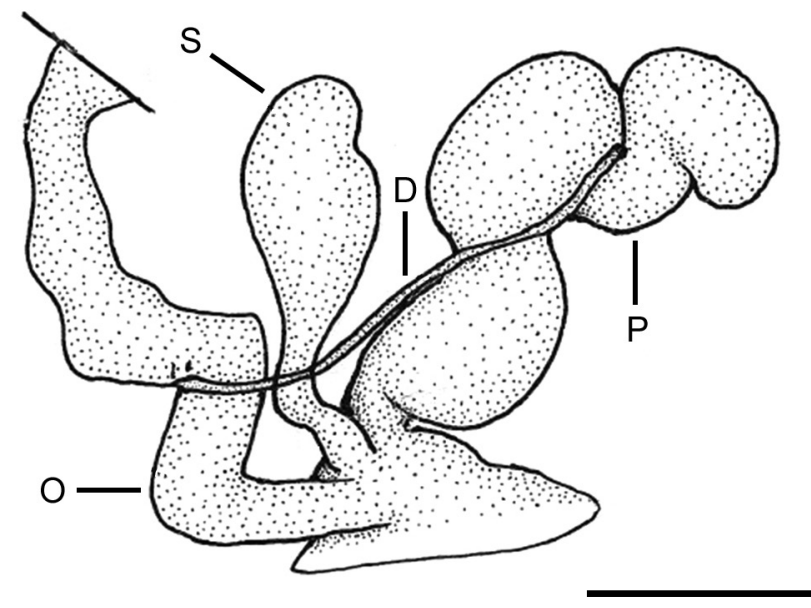

Fig. 6. Deroceras laeve, anterior parts of genital tract. Penial retractor muscle not indicated. D - vas deferens; O oviductus; $\mathrm{P}$ - penis; $\mathrm{S}$ - spermatheca (= bursa copulatrix). Scale bar $1 \mathrm{~mm}$

ed by TSHeten DuKPA (Extension Agent, Gomdar Gewog) to the NPPC as a minor pest on cabbages in Samdrup District, in the extreme southeast of Bhutan (2700'12.6"N, 91³3'10.4"E; altitude $860 \mathrm{~m}$ a.s.l.). The other photograph was of a slug sighted near Jakar Dzong (Bumthang District, central Bhutan, 273'11.9"N, 9044'43.8"E; altitude 2,650 m a.s.1.) which was lodged on the BBP (2017). If confirmed, these records would suggest that this slug is very widespread in Bhutan. Current evidence suggests that it is an agricultural pest that only causes limited 


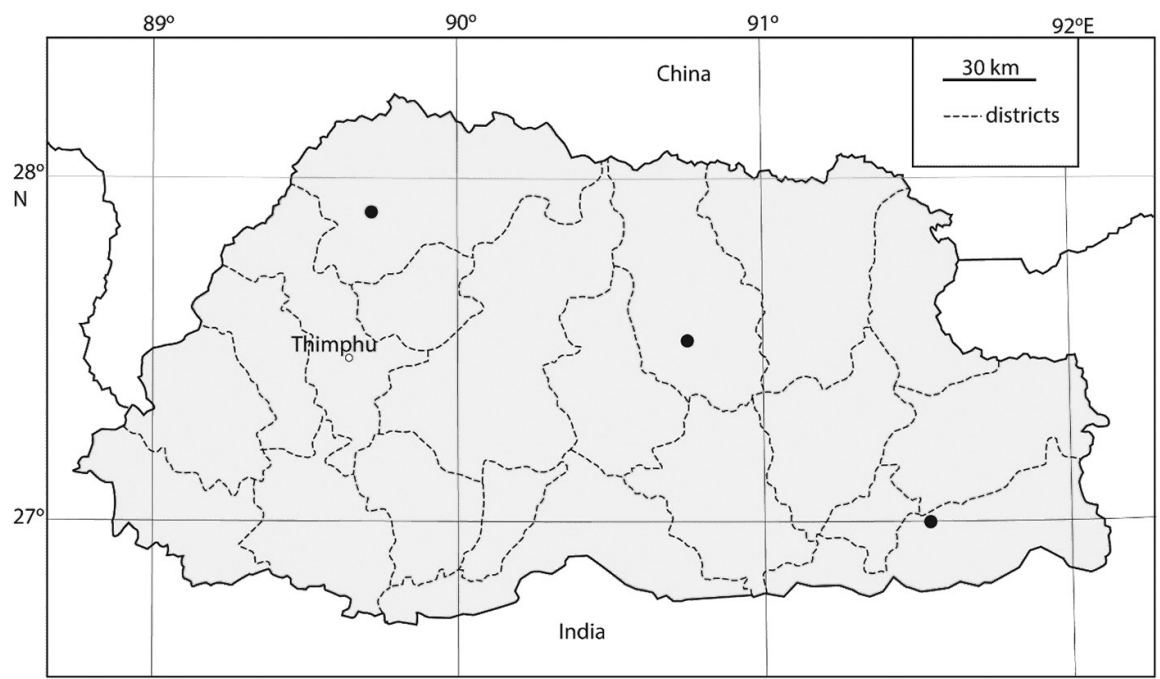

Fig. 7. Location records of Deroceras laeve in Bhutan. Only record from Gasa (north-west) was confirmed through dissection. Records from Bumthang District (central) and Samdrup District (south-east) were identified from photographs

and localised damage, which is consistent with its status elsewhere (CABI 2017).

Only the shape of the penis enables a definite identification as D. laeve. Similar euphallic specimens have been described and illustrated in an extensive monograph on the Agriolimacidae by WIKTOR (2000: 463 , figs 334 , 336-338; 464, figs 339-345, 347). We could not locate the site of insertion of the inconspicuous penial retractor muscle and omitted it in Fig. 3. Glandular small penial papillae, as described and illustrated by WiKTOR (2000), were not seen. The only clear difference between the three dissected specimens from Bhutan and the descriptions and illustrations of $D$. laeve by WIKTOR (2000) was the lack of a separate genital atrium. According to WIKTOR (2000: 463) the atrium is "unusually long" in D. laeve. A relatively long genital atrium is also figured for euphallic D. laeve by GITTENBERGER et al. (1970: 136, fig. 127a) and by CASTILLEJO (1997: 60, fig. 10c, d, f). Taking the variability in the structure of the genital tract into account, we prefer to consider the small genital atrium as one more variation, without further taxonomic consequences.

Deroceras laeve is nearly cosmopolitan (WIKTOR \& AUFFENBERG 2002, WELTER-SCHULTES 2012). Its native origin remains uncertain. Some authors refer to it as Palaearctic in origin (WELTER-SCHULTES 2012), but WiKTOR \& AUFFENBERG (2002) and SYSOEV \& SCHILEYKO (2009) for example regard it as a Holarctic element. The distributional data that have been published for mainland Asia are probably more indicative of the activity of malacologists in that region, than illustrative of the real distribution of this slug. WiKTOR et al. (2000: 31, 33 map 14) consider D. laeve as indigenous in China, where it has been recorded at many places over nearly the entire country, except for Tibet. WiKTOR \& AUfFENBERG (2002) published many records for Pakistan, where it occurs at higher altitudes in the northern half of the country. They suggested (p. 13) that "the Himalayan foothill region may be its southernmost natural occurrence in south Asia". HLAVÁč (2004) published additional data regarding the occurrence in Pakistan, and it has also recently been reported from Nepal (BUDHA et al. 2015). Genetic studies are needed to help identify the native origin, but the existing distributional data at least suggest that $D$. laeve has been present, but previously overlooked, in Bhutan and Nepal for some time. It has also been reported from the Indian states of Manipur and Mizoram (RAMAKRISHNA et al. 2010), situated roughly $450 \mathrm{~km}$ southeast of Bhutan. The status as introduced or native in this apparently isolated part of the range is not known.

Globally, the range of $D$. laeve spans very diverse habitats, from sea-level to $4,800 \mathrm{~m}$ and from Arctic tundra to mesic and tropical forests and fields (BARKER 1999, CABI 2017). It mostly occurs in moist habitats such as wet marshes and river banks where it can survive prolonged submergence, but can sometimes be found in greenhouses and as a garden pest (WIKTOR 2000, WHITE-MCLEAN 2011, CABI 2017). The apparently wide distribution in Bhutan is therefore unsurprising. Elsewhere D. laeve has been reported to breed both sexually and uniparentally (BARKER 1999). It has a very short lifecycle. DANKOWSKA (1996) reports 40 days for the complete lifecycle, i.e. the time from hatching to first egg-laying and subsequent embryonic development. Adults can survive up to a year, and breeding can occur throughout the year (WIKTOR 2000, CABI 2017).

In Bhutan it has been recorded only on cabbage. However, it is omnivorous, being able to supplement its diet of living plants and litter with faeces, carrion and even living, slow-moving animals such as earth- 
worms and insects caught in spider webs (BARKER 1999). Elsewhere it has been recorded from a wide range of crops, including broad beans (Vicia faba) and Brassica species in rural villages (WIKTOR et al. 2000, CABI 2017). We would therefore expect further surveys in Bhutan to record it on a much wider range of crops. However, the apparently small scale of the outbreaks suggests that it can readily be managed through manual removal, although early intervention is advised given the short lifecycle.

\section{REFERENCES}

BARKER G. M. 1999. Naturalised terrestrial Stylommatophora (Mollusca: Gastropoda). Fauna New Zeal. 38: 1-253.

BBP 2017. Bhutan Biodiversity Portal. Available from: http://biodiversity.bt (accessed 10 December 2017).

Bigger M., Padgham D., Pradhan N. K., Dorji C. 1988. A check list of insects and mites of Bhutan. E.E.C. Plant Protection Project, Department of Agriculture, Thimphu, Bhutan.

Budha P. B., NAggs F., Backeljau T. 2015. Annotated checklist of the terrestrial gastropods of Nepal. ZooKeys 492: 1-48. https://doi.org/10.3897/zookeys.492.9175

CABI 2017. Datasheet: Deroceras laeve (meadow slug). http://www.cabi.org/isc/datasheet/85751

CAstillejo J. 1997. Babosas del Noroeste Ibérico. Universidade de Santiago de Compostela, Santiago de Compostela, Spain.

DANKOWSKA E. 1996. Morphology and life history of Deroceras leave (Müll.) (Gastropoda: Stylommatophora: Agriolimacidae) in greenhouse conditions. Roczniki Nauk Rolniczych, Seria E 25: 91-95.

DOE DOE 2009. Integrated pest management activities in Bhutan. In: SHAMSUL ALAM M., KABIR W., NURUL ALAM M. (eds). Status of integrated pest management (IPM) in SAARC countries. SAARC Agricultural Centre, Bangladesh, pp. 49-72.

GitTenberger E., BACKhuYs W., Ripken T. E. J. 1970. De landslakken van Nederland. Bibl. Kon. Nederl. Natuurhist. Ver. 17: 1-177.

HLAVÁČ J. Č. 2004. A new record of Deroceras laeve (O. F. Müller, 1774) from Pakistan (Gastropoda: Pulmonata:

\section{ACKNOWLEDGEMENTS}

We are grateful to an anonymous referee, who called our attention to the publication of DANKOWSKA (1996). We thank CHADO TSHERING (Gasa Farm House) for access to his farm. RIEKS VAN KLINKEN was supported by the Australian Volunteers for International Development Program (Australian Government).

Agriolimacidae). Folia Malacol. 12: 181-182. https:// doi.org/10.12657/folmal.012.016

RAMAKRISHNA, Mitra S. C., DEY A. 2010. Annotated checklist of Indian land molluscs. Rec. Zool. Survey India. Occ. Paper 306: i-viii, 1-359.

RNR Statistical Coordination Section 2015. Bhutan RNR Statistics 2015. Policy and Planning Division, Ministry of Agriculture and Forests, Bhutan.

Sysoev A., SCHILEYKO A. 2009. Land snails and slugs of Russia and adjacent countries: Pensoft, Sofia - Moscow.

WELTER-SCHUltes F. 2012. European non-marine molluscs, a guide for species identification. Planet Poster Editions, Göttingen.

WHITE-MCLEAN J. 2011. Terrestrial Mollusc Tool. USA: USDA-APHIS-PPQ-Centre for Plant Health Science and Technology. http://idtools.org/id/mollusc/

WIKTOR A. 2000. Agriolimacidae (Gastropoda: Pulmonata) - a systematic monograph. Ann. Zool. 49: 347-590.

Wiktor A., Auffenberg K. 2002. Contribution to the knowledge of the terrestrial slugs of Pakistan. Folia Malacol. 10: 9-15. https://doi.org/10.12657/folmal.010.002

WikTor A., DE-NiU C., Ming W. 2000. Stylommatophoran slugs of China (Gastropoda: Pulmonata) - prodromus. Folia Malacol. 8: 3-35. https://doi.org/10.12657/folmal.008.002

Received: December 13th, 2017

Revised: March 4th, 2018

Accepted: March 6th, 2018

Published on-line: April 30th, 2018 